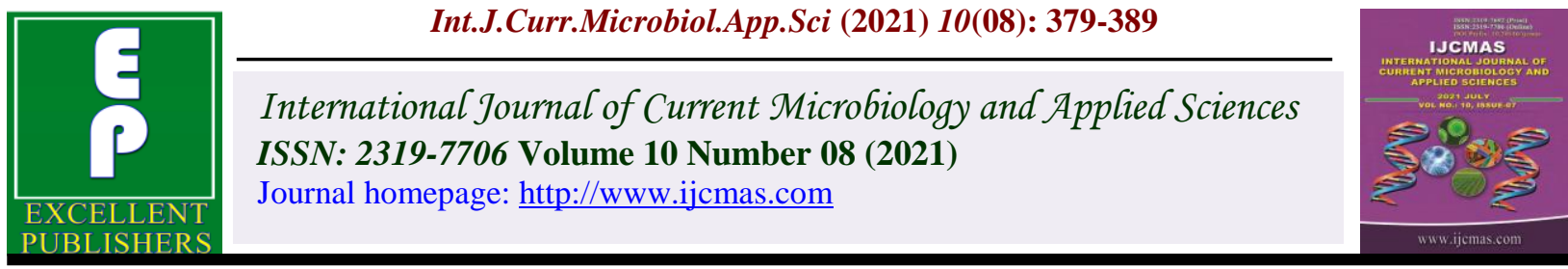

\title{
Child Poverty and its Dimensions: An Experimental Measurement in Jharkhand
}

\author{
Sk Mosharaf Hossain* \\ Department of Agricultural Economics, Institute of Agriculture Science, \\ Siksha O Anusandhan (Deemed to be University), Bhubaneswar, India \\ *Corresponding author
}

\section{Keywords}

Child poverty, poverty dimension, multidimensional poverty analysis, poverty cut off, poverty dimensions

Article Info

Accepted:

20 July 2021

Available Online:

10 August 2021

\section{A B S T R A C T}

The nature of child poverty is distinctively different from adult poverty in comprehension, measurement, and implications. In order to measure different facets of child poverty, 16 relevant child poverty factors were chosen and grouped into three poverty dimensions-deprivation, exclusion, and vulnerability. Then a multidimensional poverty study was employed with 300 randomly selected children in Palamu and Garwaha districts of Jharkhand, India to comprehensively estimate child poverty and its major contributing factors. This study also sought to understand if household income is correlated with the degree of poverty experienced by children. The study further experimented if child poverty was associated with gender. The study highlighted that the mean multidimensional poverty is estimated to be 0.48 and it ranges from 0.13 to 0.69 . With a poverty cut-off of $0.4,75 \%$ of children fall into the poverty bracket. If the cut-off is lowered to $0.3,98 \%$ of children become poor. Sanitation (12.42\%), inadequate shelter (10.7\%), political conflict (10.4\%), inaccessibility to water $(10.1 \%)$, and discrimination on the basis of poor economic status $(9 \%)$ are the major contributors to overall child poverty. When analyzed poverty dimension-wise, deprivation contributes $52.98 \%$ followed by exclusion $(24.33 \%)$ and vulnerability $(22.69 \%)$. Gender segregated poverty level was 0.4775 and 0.488 for boys and girls respectively and this was found statistically not different and it shows child poverty in the study areas strike male and female children equally. The correlation of child poverty and household income was reported to be poor, indicating that child poverty factors are not sufficiently minimized by the income of the parents.

\section{Introduction}

The word "poverty" bears different connotations, for different people, in different places and contexts. Unlike adults, children feel poverty quite differently since a child's requirements for optimal growth and psychosocial development are different from an adult. A child experiences poverty not only through lack of economic goods but also 
through several social, cultural, and political factors and three domains of child poverty are major considerations Deprivation, Exclusion, and Vulnerability which are interrelated (Wordsworth, D et al., 2005). Incomeconsumptions based poverty line measurements do not provide us any insights about the multitude of other aspects of deprivation impacting children's lives, such as access to water, shelter, health services, education etc (Boyden, J. and Feeny, T., 2003). This essentially means child poverty is multidimensional in nature and should be estimated using an appropriate measurement technique.

The significance and multifaceted nature of child poverty are well recognized. It has gradually been shaped as a special domain in development works and received special attention from many quarters. Nature, dimension, and definition of child poverty have been meticulously enunciated by academicians, sector experts, and many development organizations through wellresearched empirical evidence. Even though quite a few attempts have been made to comprehend different dimensions of child poverty beyond considering merely the parents' income, however, there exists a gap in the metric measurement of child poverty through a robust index that comprehensively includes all key factors that presuppose optimal child development. A social problem without a concrete definition is disarray. A problem definition without a valid measurement leads to inaction. Besides, it is equally imperative to measure the contribution of different factors and dimensions to child poverty in order to target precise intervention to ameliorate the situation. There exists a knowledge gap about the association of gender and parents' income with the degree of child poverty. When this aspect is understood well, poverty mitigating measures will be rationally targeted and impactful.
Against this context, a study was undertaken in two districts-Garwaha and Palamu of Jharkhand in 2019 with the following objectives.

To conceptualize and formulate a framework to construct multidimensional child poverty in the study area.

To assess child poverty status in the study area and explore how various factors and dimensions affect children's wellbeing and lead to child poverty.

To study if the household income and gender of child are associated with the incidence of child poverty.

\section{Materials and Methods}

Oxford Poverty and Human Development Initiative (OPHI) pioneered the multidimensional measurement of child poverty (Alkire, S. and Foster, J.E. 2008)but OPHI methodology largely takes into account materialistic deprivation in child poverty, ignoring other key dimensions like vulnerability and exclusion (Roche, J.M. 2013). Therefore, conceptualization and measurement of child poverty with three key poverty domains-deprivation, vulnerability, and exclusion assume valid significance for states, especially poorer state like Jharkhand that lags behind key development indices.

This study was undertaken in the Garwha and Palamu districts of Jharkhand. Two blocks Ranka (Garwha) and Satbarwa (Palamu) were purposively selected. 15 villages from each block were selected through randomization and 10 children (10-14 years) with a malefemale ratio of 50:50 were randomly chosen. Thus 150 children from each of these blocks constitute a total sample size of 300 (150 boys and 150 girls). Each child for whom information is collected is a sampling unit. 
The primary respondent was a child in the age bracket of 10-14 years. Where necessary, information was collected from parents and other key players in the village. Girls and boys have an equal share in the total sample size. A questionnaire was designed and used in collecting information about the factors that define child poverty

\section{Conceptual Note}

This study used Deprivation, Exclusion, and Vulnerability dimensions for the indexation of child poverty. These three dimensions are conceptualized as below.

\section{Deprivation}

This dimension looks at the experiences of child impoverishment about their material conditions and access to basic services.

\section{Exclusion}

It connotes the processes through which a child or a group of children are wholly or partially marginalized and they find challenging to participate in society.

\section{Vulnerability}

This dimension essentially implies the dynamic nature of children's experience of poverty in terms of how they are affected by, or resilient to, the array of changing threats in their environment.

Each of these three dimensions has a combination of factors that explicates that particular dimension. The table below details out.

\section{Scoring Technique}

Each factor under three dimensions will be measured by 0 or 1 where 1 will mean that child is poor in that particular factor. If he or she is found to be non-poor for a factor, the score assigned will be 0 . The majority of these factors (except under the deprivation dimension) are perception measurements in nature. A child's perception and experience for a particular factor were taken as accurate information without imposing anything normatively.

\section{Level of poverty measurement}

Collected data were grouped dimension-wise and tabulated in order. When we have data for all factors for all surveyed children, a composite poverty index was constructed giving equal weightage to each factor. Thus poverty score for a particular child has been calculated using boxed mathematical expression and it will be called multidimensional poverty as it takes into account different dimensions.

$C i=W 1 I_{1}+W 2 I_{2}+\ldots+W d I_{d}$

Where $\mathrm{Ci}$ is the multidimensional child poverty of $i^{\text {th }}$ child and value of $C i$ ranges from 0 to $1 ; \mathrm{W} 1$ is the weightage of indicator or factor $\mathrm{I}_{1} . \mathrm{I}_{1}$ is 0 if the child is not poor in the $I_{1}$ indicator and 1 if the child is poor for this indicator. In this study, the assigned weightage of all 16 indicators (grouped in three dimensions-Deprivation, Exclusion, and Vulnerability) is equal weightage i.e 1/16.

Therefore, here $\mathrm{W} 1=\mathrm{W} 2=\ldots . .=\mathrm{Wd}=1 / 16$.

The score thus calculated will take the numerical value from 0 to 1 . Where 0 is no incidence of overall poverty and 1 will denote the maximum possible quantum of poverty. For further simplification, if a child scores 0 it will explain he or she is not poor in any of those 16 factors. On the other hand, a score of 1 will tell us that a particular child is poor in all the listed factors. In this way, we will get a 
poverty score for each child. Thereafter poverty cut-off mark is fixed as 0.4 . It means a child will be called multidimensionally poor only if his or her total score is above 0.4 . The cut-off mark was arrived at by brainstorming it among sector experts.

Thus poverty headcount ratio and poverty intensity were worked out using simple descriptive statistical tools. The important component--poverty intensity (sometimes called breadth) is the average poverty score of all children who come under the poverty bracket (with more than 0.4 scores) and it can be expressed as:

Headcount Ratio $=n / N ; n$ is the number of poor children with the cut off mark, $N$ is the total number of children

$A($ Poverty intensity $)=M P S / n$; Where MPS is the total score of those who are multidimensionally poor, $\mathrm{n}$ is the number of such poor children.

This score will help us in comprehending how intensively poverty is spread out among poor children.

\section{Breaking down poverty score by dimensions and factors (or indicators)}

To look into the contribution of different indicators (or factors) under three dimensions to the overall multidimensional poverty score of a child, the headcount ratio for a particular factor is obtained by adding up the number of children poor in that factor and dividing it by the total number of children. Once it is computed for all factors, average child poverty for all children can be quantified by the following expression:

Average Multidimensional Child Poverty
$($ AMCP $) \quad$ for all children=
$\mathrm{a}^{*} \mathrm{f} 1+\mathrm{a} * \mathrm{f} 2+\ldots \ldots . .+\mathrm{a} * \mathrm{f} 16$ where ' $\mathrm{a}$ ' is the

weightage attached to a factor which is $1 / 16$ since there are a total of 16 factors. F1 is the headcount ratio for that factor 1 .

For example, in the case of factor nutrition, $\mathrm{a}=1 / 16$ and $\mathrm{f} 1$ is the ratio between the number of children poor in this factor and the total number of children which is $23 / 150=0.153$. Mathematically, each part of the above expression (i.e $\left.a^{*} f 1, a^{*} f 2 \ldots ..\right)$ is the contribution of that factor to AMCP. Therefore, the percentage contribution of each factor to overall poverty can be computed as follows:

Contribution of factor 1 (nutrition) = $\left(a^{*} f 1\right) * 100 / A M C P$. The contribution of all factors will sum to 100 percent.

\section{Gender on child poverty}

To understand if child poverty differs across gender, child poverty scores of children are run through an independent sample t-test where the test variable is child poverty and gender is the grouping variable. This statistical test helped us determine if the mean child poverty of male and female children is significantly different. This statistical function was performed using SPSS.

\section{Results and Discussion}

All the children in the study belong to the tribal community of Ranka block of Garwha and Satbarwa block of Palamu district. Their parents are majorly (83\%) daily wage earners and engaged in farming activities. In lean season they $(58 \%)$ migrate to nearby cities in search of livelihood. The average household size was found to be 6.23 and the average monthly earning of Rs. 3325, an amountmeager for the sustenance of family members. The mean age of the 300 surveyed children was 12.8 years.. As per records, all these children are enrolled in schools. 
Average Multidimensional Child poverty (AMCP)

When AMCP was computed for all children and analyzed, it was observed that it ranges from 0.13 (least poor) to 0.69. So the maximum poverty recorded for a child was 0.69 which can be considered a severe level of child poverty. The mean poverty level was estimated to be 0.48 and it underlines how extensively children experience poverty. It further puts forth the fact that many of those needs and care essential for children's survival and development are missing or simply not met in the study area. Therefore, this high multidimensional poverty level alone is a trigger to think and act on developmental issues that are directly linked to the wellbeing of children. Child poverty scores for all 300 children are quite normally distributed with a standard deviation of 0.10 and a median 0.48 .

\section{Child Poverty Headcount Ratio with cut-off}

When we measure the incidence of poverty with a cut-off level $0.40,113$ of 150 children came into the poverty fold which translates to $75.33 \%$ (Headcount ratio) children are poor in this multidimensional framework. Even when the cutoff is raised to 0.50 , still shockingly $60 \%$ of children turned out to be poor. Furthermore, the worrying fact is that a sizeable percentage of children (23\%) is scoring just below the cutoff mark 0.4 and can fall into the poverty trap anytime soon. Therefore, logically, if this grim situation of child poverty is to be altered with interventions, children those are close to poverty cut off mark should not be excluded.

Each of these 16 factors is crucial for a child's prosperity, so a child cannot be denied any of those 16 enabling factors. So to calibrate this measurement, the cut-off mark is further lowered down to 0.3 and surprisingly $98 \%$ of children (294 out of 350) came to be counted as poor. Interestingly, all these revelations direct where and how much the works to be done to lift these unfortunate children from the poverty trap.

\section{Factor contribution to poverty}

Mean poverty level or average multidimensional poverty is recorded 0.48 which by any standard is alarming. Analysis has broken this poverty level into factors and it was revealed (Fig 2) that sanitation with its $12.42 \%$ contribution becomes the biggest challenge to extricate children out of the poverty trap. It was closely followed by shelter $(10.7 \%)$, political conflict $(10.4 \%)$, and water $(10.1 \%)$. These figures quite evidently bring back the rousing discussion of providing children with very basic needs for their sustenance and development. Sanitation---an important child development parameter is abysmally under attained in the study area as it made up $12.42 \%$ in overall mean poverty of 0.48 . Shelter and water two basic components of human life are not adequately ensured for the children---a fact sticking out with much despair and despondency. It further emphasizes that if an effort is ever made to bring down child poverty-shelter, political conflict, and water must be worked on a priority basis. Political conflict is one of the highest poverty contributors. The high incidence of red-wing extremism activity may be a reason behind it.

Other important poverty contributors are "Exclusion" based on economic status (8.63\%), Socio-cultural bias (8.28\%) --- which are long-standing developmental issues that need social remedies. These are closely followed by the education factor (6.47) which has a significant connotation as this factor measures the learning skill acquisition of those children. There are unending discussions and relentless deliberation on poor learning outcomes of children in school especially 
since with Right to Education Act, 2009 (RtE) is in effect.

This apart, gender and age-based exclusion importantly made up $4.40 \%$ and $3.02 \%$ respectively to mean poverty level. Balancing out social dynamics and behavior change are often prescribed to break these predicaments.

Local crimes (loot, robbery, communal flareup etc) have also a sizeable share in poverty (3.45\%). The agrarian economy of the region is often plagued by the very nature of rain-fed farming. When farming practice is hit by drought, children with little coping mechanism and resilience of the family, suffer the vulnerability. The score for this factor is $4.75 \%$. Quite interestingly and contrary to the general perception, two important factorsnutrition and health account for only $1.98 \%$ and $3.02 \%$ respectively. It postulates children in the study area are not much trapped into these two poverty contributors-an encouraging revelation for those entrusted with child development. Multipronged state efforts and interventions by some of the nonprofit agencies in improving health and nutrition outcomes presumably worked well as a lesser number of children were recorded deprived in health and nutrition.

\section{Poverty dimensions and their share in poverty}

When factors are grouped into dimensions and dimensional contribution was analyzed, it was found (Fig 3) deprivation has the largest share and it is almost 53\%, distantly followed by exclusion (24.33\%) and vulnerability (22.69\%). It is noteworthy that, deprivation as a dimension, measures 7 factors and their contribution to poverty is high.
Another observation that creates space for debate and discussion is that despite 'exclusion' has 4 factors but contribution is slightly more than 'vulnerability' which comprises 5 factors. Clearly, it explained children in the study area are more prone to factors that make them 'exclusion' than those that bring them to be 'vulnerable'.

It certainly calls for policy intention and urgent action to mend this fiasco before it further slips down. Dimensional along with factor-wise decomposition of child poverty is extremely helpful in pinpointing the locus where response and intervention are actually to be infused. Moreover, these observations can unequivocally provide direction on where and how many resources can be pumped into the system which will potentially bring down the poverty level.

\section{Who is poor in what?}

So far we have delved into poverty level and breaking it down into different factors and dimensions. This essentially tells us how extensively poverty is in existence among children in the study area. Now one more part of the whole analysis will throw light on who is poor in what. This will suggest who to target in which factors to eradicate child poverty. It is abundantly clear in the graphical presentation that majority of children are poor in sanitation, shelter, water and political conflict. The figure below (Fig 4) measures number of children termed poor in several factors or indicators.

Therefore, if child poverty is of interest of anybody, developmental responses can be directed to those children and factors covered as depicted below. 
Table.1 Factors and dimensions of child poverty

\begin{tabular}{|c|c|c|c|c|}
\hline S.No. & Dimension & Factor & Ideal Situation/condition & How it is scored \\
\hline 1 & \multirow{7}{*}{ Deprivation } & $\begin{array}{l}\text { Nutritiona } \\
\text { 1 Status }\end{array}$ & $\begin{array}{c}\text { Each child is with appropriate } \\
\text { nutritional status }\end{array}$ & $\begin{array}{l}\text { BMI is for each child is } \\
\text { calculated; if it is found in } \\
\text { normal range then score will be } \\
\text { 0. In other cases it would be } 1 .\end{array}$ \\
\hline 2 & & $\begin{array}{l}\text { Health } \\
\text { Outcome }\end{array}$ & $\begin{array}{l}\text { Children are free from any major } \\
\text { easily preventable diseases (TB, } \\
\text { Malaria, diarrhea, measles etc) } \\
\text { for last } 6 \text { months preceding the } \\
\text { survey }\end{array}$ & $\begin{array}{l}\text { If the condition is not met, child } \\
\text { will be assigned score } 1 \\
\text { meaning deprivation/poverty } \\
\text { for this particular factor. If the } \\
\text { case is otherwise score will be } \\
0 \text { which will denote surveyed } \\
\text { child is not deprived of this } \\
\text { essential. }\end{array}$ \\
\hline 3 & & $\begin{array}{l}\text { Access } \\
\text { o clean } \\
\text { water }\end{array}$ & $\begin{array}{l}\text { Children have access to potable } \\
\text { water in adequate quantity (at } \\
\text { least } 30 \text { liter a day) within } 100 \\
\text { meter radius of their home. }\end{array}$ & $\begin{array}{l}\text { Child has such access will not } \\
\text { be considered poor on this } \\
\text { factor hence the score will be } 0 \text {, } \\
\text { if inaccessibility reported child } \\
\text { will said to be poor with score1. }\end{array}$ \\
\hline 4 & & $\begin{array}{l}\text { Possessio } \\
\mathrm{n} \text { of } \\
\text { shelter }\end{array}$ & $\begin{array}{l}\text { Children living in a set up with } \\
\text { flooring and adequate roofing, } \\
\text { protected with boundary. }\end{array}$ & $\begin{array}{l}\text { If the condition is met, as above, } \\
\text { score will be } 0 \text {, otherwise it is } 1 \text {. }\end{array}$ \\
\hline 5 & & $\begin{array}{l}\text { Education } \\
\text { al } \\
\text { Attainmen } \\
\quad \mathrm{t}\end{array}$ & $\begin{array}{l}\text { Educational attainment is grade- } \\
\text { appropriate as measured by } \\
\text { ASER survey tool }{ }^{4} \text {. }\end{array}$ & $\begin{array}{l}\text { If the learning skill acquisition } \\
\text { is grade appropriate score will } \\
\text { be recorded } 0 . \text { If it is found to } \\
\text { be not grade appropriate } 1 \text { will } \\
\text { be assigned. }\end{array}$ \\
\hline 6 & & Sanitation & $\begin{array}{l}\text { Children own and using any type } \\
\text { of toilet and not defecating in } \\
\text { theopen }\end{array}$ & $\begin{array}{l}\text { Where children have facility } \\
\text { and using it the score will be } 0 \\
\text { otherwise it is } 1\end{array}$ \\
\hline 7 & & $\begin{array}{c}\text { Access } \\
\mathrm{o} \\
\text { Informatio } \\
\mathrm{n}\end{array}$ & $\begin{array}{l}\text { Children with access to at least } \\
\text { one broadcast media (Radio, TV) } \\
\text { for entertainment and } \\
\text { information accumulation }\end{array}$ & $\begin{array}{l}\text { If children found to be enjoying } \\
\text { this facility will be considered } \\
\text { non-poor and score will be } 0 \text {. If } \\
\text { this not the case } 1 \text { will be score. }\end{array}$ \\
\hline 8 & \multirow{3}{*}{ Exclusion } & $\begin{array}{l}\text { Economic } \\
\text { status }\end{array}$ & $\begin{array}{l}\text { Children are not anywhere } \\
\text { discriminated basing economic } \\
\text { condition of their family/parents. }\end{array}$ & $\begin{array}{l}\text { During interaction, if child } \\
\text { point outs he has to go thru this } \\
\text { discrimination score will be } 1 \\
\text { and otherwise it iso. }\end{array}$ \\
\hline 9 & & $\begin{array}{l}\text { Socio } \\
\text { Cultural } \\
\text { base }\end{array}$ & $\begin{array}{l}\text { Children are not made subject to } \\
\text { exclusion based on Socio } \\
\text { cultural line (tribal, SC, ST etc) } \\
\text { in the society. }\end{array}$ & $\begin{array}{l}\text { If child ever experiences such } \\
\text { form of exclusion it would be } \\
\text { recorded } 1 \text {, otherwise } 0 \text {. }\end{array}$ \\
\hline 10 & & $\begin{array}{l}\text { Age of the } \\
\text { child }\end{array}$ & $\begin{array}{l}\text { Situation where children are not } \\
\text { looked down on and their voices }\end{array}$ & $\begin{array}{l}\text { If child never comes across such } \\
\text { age based exclusion score is } 0 \text {, if }\end{array}$ \\
\hline
\end{tabular}




\begin{tabular}{|c|c|c|c|c|}
\hline & & & $\begin{array}{l}\text { are heard despite being little } \\
\text { agewise. }\end{array}$ & the case is otherwise it is1. \\
\hline 11 & & Gender & $\begin{array}{l}\text { Societal gender norms do not } \\
\text { become ground for } \\
\text { exclusionanywhere. }\end{array}$ & $\begin{array}{l}\text { During interaction, if child } \\
\text { point outs he has to go thru } \\
\text { such gender based exclusion, } \\
\text { score will be } 1 \text { and otherwise it } \\
\text { is0. }\end{array}$ \\
\hline 12 & & $\begin{array}{l}\text { Political } \\
\text { Conflict }\end{array}$ & $\begin{array}{l}\text { Political conflict/violence in any } \\
\text { form do not impact and harm } \\
\text { young minds }\end{array}$ & $\begin{array}{l}\text { If interviewed child stress some } \\
\text { form of political conflict that } \\
\text { affected him negatively-will } \\
\text { give this child score } 1 \text { in this } \\
\text { factor and in other case, it is } 0 \text {. }\end{array}$ \\
\hline 13 & $\begin{array}{c}\text { Vulnerabilit } \\
\mathbf{y}\end{array}$ & $\begin{array}{l}\text { Natural } \\
\text { Disaster }\end{array}$ & $\begin{array}{l}\text { Natural disaster such as flood, } \\
\text { drought, earthquake etc will not } \\
\text { put children at further cascading } \\
\text { risks. }\end{array}$ & $\begin{array}{l}\text { In case, natural disaster causes } \\
\text { and compounded risks for } \\
\text { children to survive and grow } \\
\text { the score is recorded as } 1 \text {, else } 0 .\end{array}$ \\
\hline 14 & & $\begin{array}{l}\text { Parent's } \\
\text { death/abse } \\
\text { nce of } \\
\text { care taker }\end{array}$ & $\begin{array}{l}\text { Every child is well accompanied } \\
\text { by parents, if parents are not } \\
\text { there, responsible caretakers do } \\
\text { the job. }\end{array}$ & $\begin{array}{l}\text { When child has to face such } \\
\text { challenges score is } 1 \text { and } 0 \text { if he } \\
\text { or she is well accompanied by } \\
\text { parents. }\end{array}$ \\
\hline 15 & & $\begin{array}{l}\text { Domestic } \\
\text { violence }\end{array}$ & $\begin{array}{l}\text { Children never confront with any } \\
\text { sort of domestic/spousal violence } \\
\text { that negatively affect them }\end{array}$ & $\begin{array}{l}\text { If domestic/spousal violence } \\
\text { jeopardizes children's well- } \\
\text { being in anyway score will be 1, } \\
\text { else0. }\end{array}$ \\
\hline 16 & & $\begin{array}{l}\text { Local } \\
\text { crime }\end{array}$ & $\begin{array}{l}\text { Local crime not potentially } \\
\text { makes children's life risky and } \\
\text { hazardous. }\end{array}$ & $\begin{array}{l}\text { When a child thinks local crime } \\
\text { is actually hampering his } \\
\text { wellbeing, it means he is poor in } \\
\text { this factor hence the score is } 1 . \\
\text { If that is not the case score will } \\
\text { be } 0 \text {. }\end{array}$ \\
\hline
\end{tabular}

Table.2 Poverty cut-off and poverty percentage

\begin{tabular}{|c|c|c|}
\hline $\begin{array}{c}\text { Poverty cut } \\
\text { off }\end{array}$ & No of poor children in this cut off & Percentage \\
\hline $\mathbf{0 . 3}$ & 294 & 98 \\
\hline $\mathbf{0 . 4}$ & 226 & 75 \\
\hline $\mathbf{0 . 5}$ & 180 & 60 \\
\hline
\end{tabular}


Fig.1 Factor contribution to child poverty

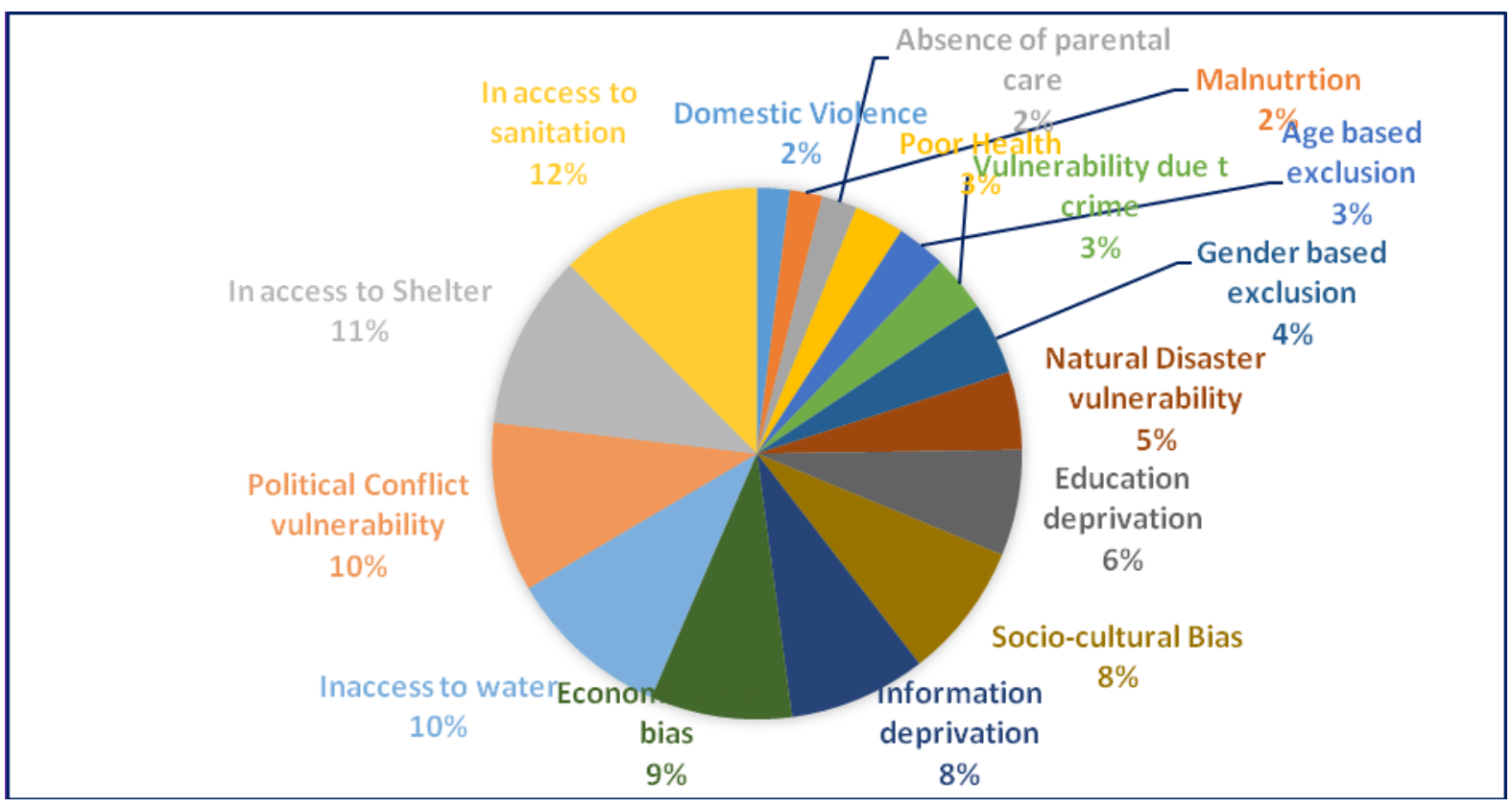

Fig.2 Poverty dimension and their share

\section{Contribution(\%) of dimensions to over all poverty}

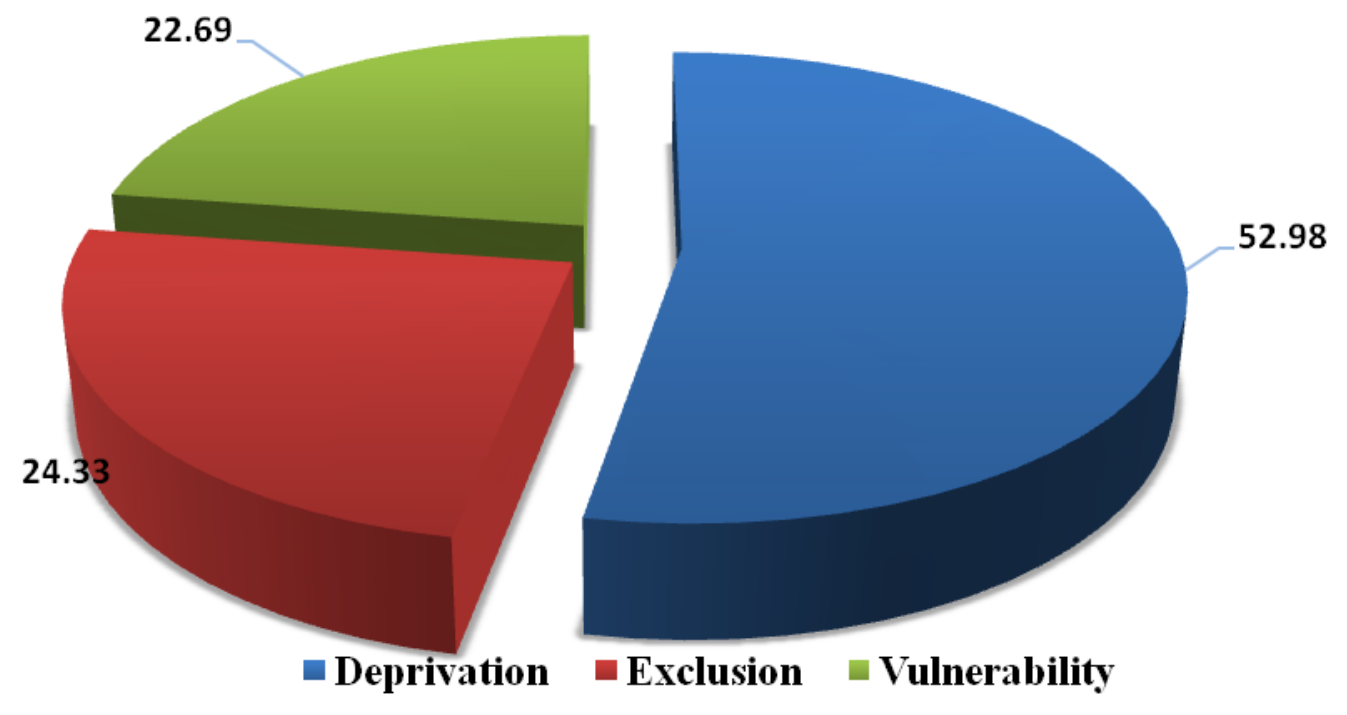


Fig.3 Number of children poor across factors

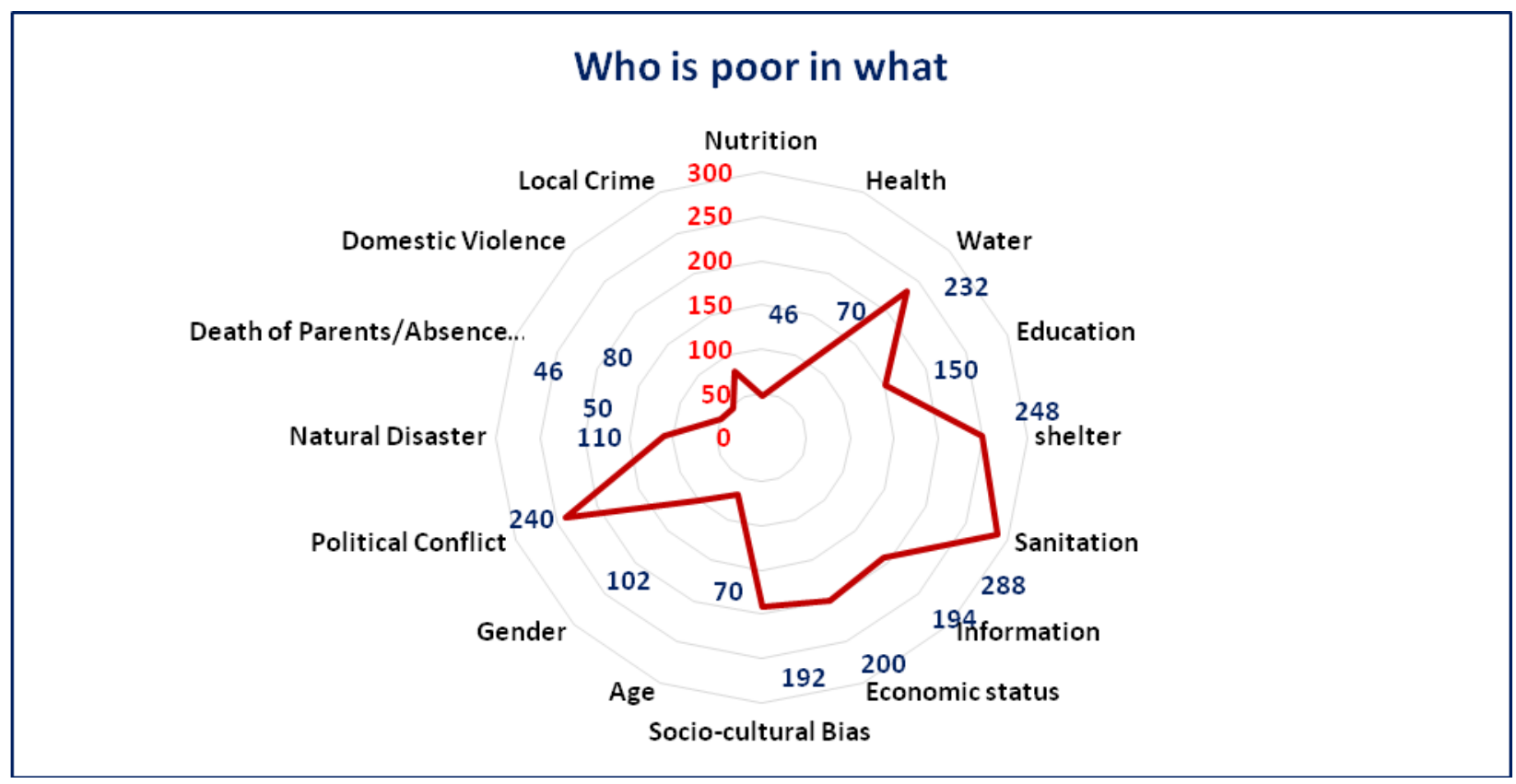

\section{Gender and child poverty}

This study further went on to investigate if there is a gender effect on child poverty. The mean poverty for girls is 0.4775 whereas it is 0.4883 among boys. Making the conclusion and claim stronger, SPSS output was referred to (independent $\mathrm{t}$ sample test) and it statistically reasoned out that there is no significant difference between mean poverty across gender ( $p$ value $=0.538$ ). Therefore, it reinforces that child poverty is not significantly different among girls and boys.

\section{Deprivation and household income}

Deprivation - the highest contributor to child poverty left space for more analytical studies. Therefore, a deprivation score has been constructed by attaching equal weightage to each of those seven factors under this dimension. The first dimension essentially captures a child's deprivation in basic needs and those are often linked to a family's financial capability. The general notion-a financially established family is more capable of meeting children's basic amenities. But it was noticed during the course of analysis that these two variables. Household income and deprivation are not highly correlated though the negative nature of correlation is revealed and it is well justified. The correlation coefficient is just 0.453 and it falsifies that general perception that more the income more the child wellbeing.

\section{Recommendations}

The mean multidimensional child poverty is measured at 0.48 which is alarmingly high and it opened up larger debate and discussion on child poverty of this region. The severity of this social issue requires a prompt and sustainable response.

With 0.4 poverty cut off, $75 \%$ of the child population is poor. Unlike adult poverty, the majority of the children are in fact languishing in a poverty trap. Strategic and continued efforts are needed to break this trap. Children who are just below 0.4 cut-off marks are significant in number. They are with a greater 
probability of falling into the poverty region. Thus it needs special attention who are engaged in advocating and promoting child development.

Sanitation, shelter, water, and political conflict constitute almost half (43.62\%) of the mean poverty. Hence any initiative and responses aimed at reducing child poverty must warrant looking into these factors on an urgent basis.

Deprivation dimension has the highest (53\%) share in child poverty which concludes factors under 'deprivation' assume a special significance in developmental initiatives for children.

Popular notion in the development sphere is girls are more deprived than boys but in this particular experiment, it is statistically established that there is no significant difference in the mean poverty across gender. This helps in formulating policies to promote child well-being.

Deprivation index alone is not largely affected by the level of family income. So it cannot be strongly concluded that more the income lesser the child poverty or vice versa. Hence it stimulates to investigate other possible issues which actually regulate the level of child poverty. Thus it will be assisting policymakers to act on the issue with more efficacy.

\section{Limitation of the study}

The study was undertaken with first-hand information about children from some of the remote and deprived areas of Palamu and
Garhwa district. It may not be representative of the general situation in Jharkhand as a whole.

Selection of factors and grouping them into dimensions to define child poverty is based on technical inputs from handful child development experts. But nevertheless it still can have room for debate and discussion.

\section{Conflict of interest}

The authors report no potential conflict of interest.

\section{References}

Alkire, S. and Foster, J. E. Counting and Multidimensional Poverty Measurement, working paper No 7, Oxford Poverty and Human Development Initiative, University of Oxford, 2008, 9-22

Boyden, J. and Feeny, T. (2003). A Review of Contemporary Literature and Thought on Children and Poverty, Christian Children's Fund (CCF), Children and Poverty Series Pt I, Richmond, USA, 2003, 21-39

Roche, J. M. Monitoring progress in child poverty reduction: Methodological insights and illustration to the case study of Bangladesh, working paper No 45,University of Oxford, 2013, 4-9

Wordsworth, D., Mcpeak, M., and Feeny, T. (2005). Understanding children's experience pf poverty: An introduction to DEV framework, working paper 1 , $C C F, 2005,6-22$.

\section{How to cite this article:}

Sk Mosharaf Hossain. 2021. Child Poverty and its Dimensions: An Experimental Measurement in Jharkhand. Int.J.Curr.Microbiol.App.Sci. 10(08): 379-389.

doi: https://doi.org/10.20546/ijcmas.2021.1008.046 